\title{
The use of restorative justice for environmental crimes in the European Union's legal framework
}

\begin{abstract}
Stefano Porfido*
ABSTRACT Restorative justice is a way of responding to criminal offences by balancing the needs of the community, the victims, and the offenders. It aims to bring all these parties together to collectively resolve the consequences of crime, including the harm caused, with a view to future generations. In the European Union (EU), restorative processes have not yet been used to deal with environmental crimes, notwithstanding a growing interest in exploring their potential. Therefore, this paper seeks to demonstrate that restorative justice solutions which address environmental crimes yields benefits for the victim, offender, community, and environment. Further, that these solutions enhance the current threshold of environmental protection granted by EU Member States' penal systems, in compliance with the EU'S overarching principle of sustainable development.
\end{abstract}

\section{Introduction}

On 15 November 2019, Pope Francis addressed participants of the XX World Congress of the International Association of Penal Law, stating that 'Our societies are called to advance towards a model of justice based on dialogue, on encounter, so that wherever possible, the bonds damaged by the crime may be restored and the damage repaired'. ${ }^{1}$ This paper represents attempts to respond to this challenge by promoting the adoption of a bottom-up approach to environmental crimes based on restorative justice (RJ) principles at the European Union (EU) level.

$\mathrm{RJ}$ is a holistic approach to crime that seeks to restore parties to the positions they were in before crimes were committed, redressing the legal violations and healing social relationships. When it comes to dealing with environmental crimes, RJ promises to address the broad and complex relational dimension enshrined by the environmental harm, both in the anthropocentric and in the eco-centric realm. The reason for discussing RJ solutions framed in the EU legal order is twofold: not only has the EU proved to be strongly committed in

\footnotetext{
* PhD candidate in Law at Sant'Anna School of Advanced Studies, Institute of Law, Policy \& Development (DIRPOLIS) in Pisa (Italy) stefano.porfido@santannapisa.it.

${ }^{1}$ Pope Francis, 'Address With Participants in the $20^{\text {th }}$ World Congress of the International Association of Penal Law' (Vatican, 15 Nov 2019)

$<$ https://press.vatican.va/content/salastampa/en/bollettino/pubblico/2019/11/15/191115j.html > accessed 21 August 2020.
} 
developing policies that are attentive to environmental protection, as demonstrated by the seven Environmental Action Plans approved so far, but it also already endorses RJ practises to enhance the victim's status in penal law procedures. Therefore, whilst EU's regulative approach for counteracting environmental crimes still appears centred on traditional penal sanctions, the EU nonetheless represents a promising gateway for developing a uniform response to such crimes based on RJ principles.

This work demonstrates that RJ solutions for environmental crimes constitute an opportunity for the EU to enhance the threshold of environmental protection currently safeguarded by the Environmental Crimes Directive in compliance with the principle of sustainable development. This conclusion leads the paper to later propose a new interpretation of the "command and control" model for State's intervention. This interpretation would favour a "control" consistent with RJ principles over "command" through criminal law, this latter only being a last resort measure.

\section{A restorative justice approach for environmental crimes}

$\mathrm{RJ}$ holistically responds to criminal offences and provides an alternative to traditional retributive criminal law sanctions. ${ }^{2}$ Particularly, RJ seeks to restore parties to their previous positions before the crimes were committed, redresses the violations, and heals social relationships. ${ }^{3}$ These objectives are pursued by bringing together the victims, offenders, and communities to discuss the crime committed and actively participate in rectifying the consequential harm. This section first analyses the key elements of RJ and then discusses why it constitutes a valuable remedy to tackle environmental offences, in addition to traditional penal law measures.

\subsection{Restorative justice: a definitional perimeter}

Although there is no consensus in the commentary on the definition of RJ, ${ }^{4}$ one widely accepted definition is provided by Tony Marshall who states that:

\footnotetext{
${ }^{2}$ As reported by the Centre for Justice \& Reconciliation $<\underline{\mathrm{http}}$ ://restorativejustice.org/restorative-justice/aboutrestorative-justice/tutorial-intro-to-restorative-justice/lesson-1-what-is-restorativejustice/\#sthash.n1bsTnaQ.dpbs > accessed 30 January 2021.

${ }^{3}$ According with the United Nations Office on Drugs and Crime (UNODOC), RJ aims to repair damaged relationships; support victims, give them a voice, enable their participation, and address their needs; encourage all concerned parties to take responsibility, particularly the offender and to identify restorative forward-looking outcomes. See UNODOC, Handbook on Restorative Justice Programmes (NY, 2006), 9-10.

${ }^{4} \mathrm{RJ}$ is often used as an umbrella concept to refer to different informal justice paradigms such as "relational justice", "reparative justice", "restorative community justice", "transformative justice" as noted by Fred Besthorn, 'Restorative Justice and Environmental Restoration - Twin Pillars of a Just Global Environmental
} 
"Restorative justice is a problem-solving approach to a crime which involves the parties themselves and the community generally, in an active relationship with statutory agencies [...] Restorative justice is a process whereby parties with a stake in a specific offence collectively resolve how to deal with the aftermath of the offence and its implications for the future."

Among the international legal sources that have recognised and regulated restorative processes,${ }^{6}$ this paper refers to the Council of Europe's 2018 Recommendation on restorative justice in criminal matters (Recommendation 2018), ${ }^{7}$ which is chronologically the most recent soft-law tool on this subject. It states:

"Restorative justice" refers to any process which enables those harmed by crime, and those responsible for that harm, if they freely consent, to participate actively in the resolution of matters arising from the offence, through the help of a trained and impartial third party (hereinafter the "facilitator").",

This definition, similarly to Marshall, clarifies that participatory aspects are intertwined with reparative purposes. ${ }^{9}$ This means that for an activity to be restorative, it is not sufficient that it only pursues reparative goals. Rather, these goals must stem from and be frame an inclusive participatory process between parties at stake under the supervision of a facilitator.

However, the Council of Europe's definition goes beyond Marshall's definition in several aspects. First, the free consent of parties is unequivocally affirmed as the core of RJ procedures. Second, 'those harmed and those responsible for that harm' is a more precise criterion compared to Marshall's "parties". This is because it establishes a nexus between people entitled to participate in RJ processes and the harmful consequences stemming from the crime. As such, this definition clarifies that RJ is not a neutral problem-solving tool, but rather a method of justice addressing only crime's harmful consequences and not any kind of

Policy: Hearing the Voice of the Victim' (2004) 3 Journal of Social and Societal Policy 33. The lack of a common definition of Restorative Justice is considered a major flaw by Andreas Von Hirsch et al, 'Specifying Aims and Limits for Restorative Justice: A “Making Amends" Model?' in Andreas Von Hirsh, Julian Roberts, Anthony Bottoms, Kent Roach and Mara Schiff (eds) Restorative Justice and Criminal Justice. Competing of Reconcilable Paradigms? (Hart 2003) 22.

${ }^{5}$ Tony Marshall, Restorative Justice: An overview. (London 1999), 5.

${ }^{6}$ Among the others, ECOSOC Resolution 2002/12 on the Basic Principles on the Use of Restorative Justice Programmes in Criminal Matters; UNODOC Principles (n 3).

${ }^{7}$ Council of Europe, 'Recommendation of the Committee of Ministers to member States concerning restorative justice in criminal matters' (2018) CM/Rec(2018)8. See also its Commentary CM/Rec(2018)115

$<$ https://search.coe.int/cm/Pages/result_details.aspx?OObjectId=09000016808cdc8a $>$ accessed 20 June 2020.

8 Recommendation 2018 \$3.

${ }^{9}$ In this paper, reparation is meant as restitutio in integrum. 
stakeholders' interest. This conclusion and the requirement that parties must be assisted by a facilitator, reveals a precise indication about the public nature of RJ procedures, thereby preventing a privatisation of the response to crime.

\subsubsection{Restorative justice programmes}

Restorative processes involve a dialogue between the victim and the offender. Consistently with Recommendation 2018, this paper defines offenders as 'those responsible for the harm'. ${ }^{10}$ The term 'responsible' does not amount to judicial finding of legal guilt, making it consistent with defendant's presumption of innocence if restorative procedures take place before sentencing. ${ }^{11}$ Most common modalities are victim-offender mediation (VOM) and family/community group conferencing. VOM programs are based on mediation techniques and involve a third party (mediator or facilitator) proactively assisting the victim and offender to personally confront each other. This results in a shared learning experience regarding the reasons for and the consequences of the offence and future steps toward voluntary harm reparation. VOMs programmes are mostly found in the European context. ${ }^{12}$

Family and community group conferences have been developed in New Zealand and they mostly parallel VOMs approaches. Unlike VOMs programmes, family and community programmes are more inclusive, typically involving the victim/offender's relatives as well as other community support persons and agencies (such as the police). Furthermore, the role of the third person is narrower and limited to mainly granting a safe process for all. Therefore, in family and community programmes dialogue between parties is facilitated and not mediated by the third person. Thus, such programs allow parties to establish a more direct and personal confrontation. ${ }^{13}$

$\mathrm{RJ}$ programmes take place either as a diversion from prosecution or they are integrated in the criminal justice process. In the first case, referred to as the front-end model, the restorative programme and the eventual agreement are outside the court's oversight. When RJ programmes are integrated in the criminal justice system, known as the back-end model, the

\footnotetext{
${ }^{10}$ Accordingly, victims also are intended as those harmed by the crime.

${ }^{11}$ Commentary to Recommendation 2018 (n 7) Rule 3.

${ }^{12}$ Christa Pelikan, Thomas Trenczek Victim offender mediation and Restorative Justice: A Global Perspective (Routledge 2006), 64.

${ }^{13}$ For a deeper description of these and other models, see Hemma Mayrhofer et al., 'Catalogue of Restorative Justice approaches, practises and tools' (2010), 19

$<$ https://corepol.eu/findings/documents/D2_1_Catalogue_of_Restorative_Justice_approaches.pdf access19 October 2020> accessed 20 June 2020.
} 
agreement is returned to the court and taken into consideration when sentencing the offender. ${ }^{14}$ Therefore, in back-end models courts retain their oversight over the case and monitor the fulfilment of RJ agreements. These agreements are legally binding as they are part of sentencing. This integrated approach occurs at any stage of the criminal justice process. This includes before trial (pre- or post- charge), or after conviction (pre- or post- sentencing the offender). ${ }^{15}$

However the RJ program functions, it must comply with basic RJ tenets. ${ }^{16}$ Particularly, in addition to participatory and reparative principles recalled earlier, the RJ process must be based on voluntary participation, on procedural fairness and most importantly, on a substantive balance between the parties. This last aspect is particularly significant and must be interpreted to exclude any practises of humiliation, degradations or annihilation from any party to the other. ${ }^{17}$ In the following section, this article considers this requirement in more depth.

\subsection{A justice that heals relations}

RJ represents a shift in the criminal justice paradigm from a traditional punitive conception toward a more holistic approach to crime. ${ }^{18}$ Indeed, the typical penal law paradigm is rooted in the State's centrality and monopoly in conflict, and it conceives of crime as an attack against the State's legal order. In this state-centric paradigm, underpinned by the reaffirmation of the State's dominance over the offender, little room if any is left to consider how the crime has affected victims. This is because the main goal is to ascertain the alleged offender's legal guilt. ${ }^{19}$ Instead, RJ primarily focuses on the harm caused by crime on the relational ground, that is on the human dimension of the crime. $\mathrm{RJ}$ is precisely an approach to justice based on dialogue among parties who seek to understand the wrong committed and to heal relational wounds.

\footnotetext{
${ }^{14}$ After the charge is brought before the court by the prosecutor, if reasons for holding a RJ conference are identified, the trial is adjourned to allow the conference to occur. The conference is typically structured in four stages, namely: a pre-conference preparation stage; the facilitation of the conference itself; the formulation of the conference outcome agreement and post conference follow-up. See Hadeel Al-Alosi and Mark Hamilton, 'The ingredients of success for effective restorative justice conferencing in an environmental offending context' (2019) 42(4) UNSW Law Journal 1460, 1465.

${ }^{15}$ Recommendation $2018 \S 6$.

16 See Recommendations $2018 \S \S 13-20$.

${ }^{17}$ Ibid., $\$ 14$.

${ }^{18}$ Howard Zehr, Changing Lenses: A New Focus for Crime and Justice (Herald Press 1990); The Little Book of Restorative Justice: Revised and Updated (Good Books 2015).

${ }^{19}$ See Albin Eser, 'Bene giuridico e vittima del reato' (1997) 39 RIDPP 1061.
} 
The notion of "therapeutic justice" is very often used to describe $\mathrm{RJ} .{ }^{20}$ Braithwaite and Pettit refer to RJ as an ideal of justice that emphasizes healing rather than mere punishing: healing the victim and undoing the harm; healing the offender by rebuilding their moral and social self; healing communities and mending social relationships. ${ }^{21}$ The true essence of the term restoration, its conceptual meaning, is connected with the idea of respect and mutual recognition between parties. In this respect, Mannozzi ${ }^{22}$ suggests that the concept is roots of the concept, enshrined by the term restoration, can be traced to the Italian jus-philosopher Del Vecchio's work "La giustizia". Del Vecchio theorised an idea of justice, alternative to retribution, based on reparation rather than on revenge. ${ }^{23}$ For Del Vecchio, reparation for a criminal offence entails a process of recognition of the other as a person. This reaffirms the identity annihilated and oppressed by the crime based on a superior ideal of equalities and of non-domination. ${ }^{24}$

Beyond Mannozzi's thesis, undoubtedly the idea of non-domination represents a pillar principle in RJ discourse, ${ }^{25}$ through which the social equilibrium harmed by crime can be repaired. If RJ frames crime in its relational realm, then crime itself could not be conceived in formal terms as the breach of a legal interest established by the State. But, rather as an action to convey a message of domination, literal or symbolic, from the wrongdoer to its victim. In this respect, Murphy points out that crime is precisely a message that reflects, at least symbolically, the offender's belief or attitude to use victims, 'in Kant's language, as mere means or things to be exploited for the wrongdoer's own selfish purposes - all without any regard for the victim' rights as persons' ${ }^{26}$

\footnotetext{
${ }^{20}$ Daniel Van Ness, Karen Heetderks Strong, Restoring Justice (Anderson 1997), 32 define RJ as justice that heals.

${ }^{21}$ John Braithwaite, Philip Pettit, Not Just Deserts: A Republican Theory of Criminal Justice (OUP 1990); John Braithwaite, Restorative Justice and Responsive Regulation (OUP 2002).

${ }^{22}$ Grazia Mannozzi, 'Traduzione e interpretazioni giuridica nel multilinguismo europeo: il caso paradigmatico del termine "giustizia riparativa" e delle sue origini storico-giuridiche e linguistiche' (2015) 1 RIDPR 137. ${ }^{23}$ Giorgio Del Vecchio, La Giustizia, (IV edn. Studium 1951), 198.

${ }^{24}$ In Del Vecchio's words, “human life cannot unfold nor by means of mechanical happenings, neither by unilateral arbitral decisions, but only when different individuals grant each other reciprocal respect and cooperate together toward a common end, subordinating their own behaviours to limits and to a common norm". (translation provided by Stefano Porfido), Ibid. 96. As such, reparation in this context is a broader notion than the mere activity to repair material damages, and hence it is closer to restoration as meant in this paper.

${ }^{25}$ John Braithwaite, 'Principles of Restorative Justice', in Restorative justice and criminal justice (n 4).

${ }^{26}$ Jeffrie Murphy, 'Repentance, Mercy, and Communicative Punishment' in Crime, Punishment, and Responsibility: The Jurisprudence of Antony Duff (OUP 2011) 27, 29. Murphy frames the communicative theory of punishment, that is a theory on what punishment communicates to and about the offender, in a broader communicative theory of crime, by considering what message the wrongdoer may convey by committing the crime. On the communicative theory of punishment, see Antony Duff, Punishment, Communication and Community, (OUP 2001).
} 
While both RJ and traditional penal punishment aim to annul the crime, their strategies differ. Traditional punishment is a social ritual through which the State reaffirms the legal order by the symbolism of hard treatment. ${ }^{27}$ Conversely, RJ involves parties' active and balanced cooperation in developing a new narrative of respect and balance. As such, by adopting restorative processes, the State enables the wrongdoer to take voluntary steps to repudiate its act of domination toward both the victims and the legal order in general. ${ }^{28}$ In doing so, the offender restores and heals the relational realm broken by crime.

\subsection{Why restorative justice for environmental crimes?}

Environmental crimes are atypical for RJ ${ }^{29}$ However, take the following example:

"What if a wall of a dam containing highly toxic mining waste collapses, polluting the surrounding waterways and drinking water, killing ten thousand of fish and devastating the social and economic lives of the villages dependent on these waterways? [...] how will the imposition of a fine - the usual sanction for environmental offenses - assist the individuals and communities whose lives have been severely harmed by the criminal negligence of the company?",30

This example highlights that environmental harm is intrinsically relational. ${ }^{31}$ Environmental offences do not only affect the environment per se, i.e., the natural matrices. They also affect the people interacting with the environment due to the individual, socioeconomic and cultural concerns at stake, in present time as well as the future. ${ }^{32}$

\footnotetext{
${ }^{27}$ Ibid, 35. On freedom as non-domination see Philip Pettit, Republicanism: A Theory of Freedom and Government (OUP 1997). For Pettit, State's punishment also is a form of domination against the offender.

${ }^{28}$ Coercion through criminal law is not incompatible with offender's voluntary participation to RJ processes.

The offender is free to avoid an escalation of coercion, that is to prevent outside forces from taking over the case and to put it on a more punitive track. In this way, Braithwaite (n 21), 34-36.

${ }^{29}$ Indeed, RJ is historically a (human) victim-oriented theory of justice, as advocated by Martin Wright Justice for Victims and Offender: A Restorative response to Crime (Waterside Pres 1996).

${ }^{30}$ Femke Wijdekop 'Restorative justice responses to environmental harm' (2019), 4 $<$ https://earthrestorativejustice.org/article/35054/iucn-report-restorative-justice-responses-to-environmental-

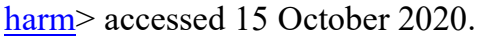

${ }^{31}$ Following Friskics' conceptualisation of human relations, 'relational' refers to multiple human interconnections permeated by a spirit of dialogue and immersed in a milieu of ambient meaning. Scott Friskics 'Dialogical Relations with Nature' (2001) 23:4 Environmental Ethics 391, 406.

${ }^{32}$ The connection between environment and socio-economic considerations has been recently recognised by the European Court of Human Rights (ECtHR), in Cordella et al v Italy, App. no. 54414/13 and 54264/15 (24 January 2019). On environmental harm and victimhood, see Matthew Hall, Victims of Environmental Harm: Rights, Recognition and Redress Under National and International Law, (Routledge 2013); 'Environmental harm and environmental victims: Scoping out a "green victimology' (2014) 20 International Review of Victimology 129. For intergenerational equity discourse, see Ben Almassi, 'Climate change and the need for intergenerational reparative justice' (2017) JAEE 199.
} 
The 2009 U.N. International Strategy for Disaster Reduction (UNISDR) embeds the relational implications of environmental harm in the notion of environmental degradation, defined as 'the reduction of the capacity of the environment to meet social and ecological objectives and needs'. ${ }^{33}$ This definition frames the damage to the environment in the context of the society that the environment supports. ${ }^{34}$ Hence, it makes clear that the sustainability of humans' health, well-being, social activities and livelihood depends upon the preservation of the environment. In this sense, environmental harm can be labelled as "ecological harm", that is a social harm that affects the relational realm between human beings and the environment. ${ }^{35}$ Such a conception refers to an eco-centric understanding of socio-ecological relations where nature enjoys an inner value that should be fairly balanced with humans' instrumental uses of it. $^{36}$

It follows that environmental harm includes the failure to develop sustainable relations between human beings and the environment, as ecological destruction and human misery are intrinsically intertwined. ${ }^{37}$ From an environmental harm perspective, the result is environmental victimhood which departs from William's static notion of the individual victim as based on injury caused by physical alterations of natural matrices. ${ }^{38}$ Rather, environmental victimhood is a collective notion that encompasses the multifaceted damages to relations between a community and its territory. ${ }^{39}$ It entails a dynamic process of environmental decline that affects the capability of a community of persons to live harmoniously in their natural surroundings.

When applied to environmental crimes, RJ is not only a technique to address criminal matters. Rather, it conceives justice as beyond inter-individual relationships and restores a holistic concept of community constituted by individuals considered as both social actors and living entities ontologically intertwined with nature. ${ }^{40} \mathrm{RJ}$ defines community as a dynamic

\footnotetext{
${ }^{33}$ UNISDR Terminology on Disaster Risk Reduction (2009) at $<\underline{\text { https://www.eird.org/eng/terminologia- }}$ eng.htm $>$ accessed 20 June 2020, 14.

${ }^{34}$ In this sense, see also U.N. Research Institute for Social Development (UNRISD) 'Environmental degradation and social integration' (Geneve 1994).

${ }^{35}$ Robert White, Transnational Environmental Crime: Towards an Eco-global Criminology, (Routledge 2011).

${ }^{36}$ Ecocentrism is based on the idea that 'humans and their activities are inextricably integrated with the rest of the natural world in communal or communal-like arrangements' Brian Steverson, 'Ecocentrism and Ecological Modeling', (1994) 16(1) Environmental Ethics 71, 72.

37 Mark Halsey, Robert White, 'Crime, ecophilosophy and environmental harm' (1998) 2(3) Theoretical Criminology 345.

${ }^{38}$ Christopher Williams, ‘An Environmental Victimology' (1996) 23(1) Social Science 16.

${ }^{39}$ In this sense, see White (n 35), 122.

${ }^{40}$ Besthorn (n 4), 43; see also Fred Besthorn 'Radical Environmentalism and the Ecological Self: Rethinking the Concept of Self-Identity for Social Work Practise’ (2002) 13 Journal of Progressive Human Services 53.
} 
experience $^{41}$ which is designed to shape a social-ecological system in which anthropocentric and eco-centric dimensions constitute a unicum. ${ }^{42}$ In this respect, environmental crimes are an act of domination, in the sense seen above, toward such dynamic idea of community. Through the perpetration of environmental offences - such as the pollution of a river, the contamination of ground water or the poisoning of soils used for agriculture - the wrongdoer jeopardises the community's freedom to interact with its own environment. In tackling such offences, RJ aims at restoring an ideal of community based on a universal kinship of life in which humans do not dominate, exploit, or destroy. ${ }^{43}$

This appears to be RJ's added value in this field when compared with traditional retributive criminal penalties. While the State can enforce a significant penalty to punish the offender and order environmental reparations, the relational dimensions encompassed by environmental crimes, in the present as well as in the future, would not be addressed sufficiently by such measures. ${ }^{44}$ Relational complexity is a core element of RJ. Restorative remedies, being ontologically dialogical and inclusive, promise to tackle environmental damage not per se, but vis-à-vis the broader harm to relation. Thus, restorative solutions are better suited than traditional punishments to rebalance the anthropocentric and eco-centric components embedded in environmental harm. In this respect, Preston is a pioneer in advocating that RJ represents an opportunity for parties to repudiate the polluter's misconduct by developing a new narrative based on a better awareness of and sensibility toward environment's inner value. ${ }^{45}$ In the following section, New Zealand's experience in the field of RJ for environmental crimes will be reported to support this theoretical background.

\section{Restorative Justice for environmental crimes in New Zealand}

\footnotetext{
${ }^{41}$ As suggested by Roberto Esposito, Communitas: The Origin and Destiny of Community (SUP 2010), 2.

42 John Dryzek, 'Institutions for the Antropocene: Governance in a Changing Earth System' (2016) 46 B J Pol Sci 937, 941. For the Author, social-ecological systems are linked social systems and ecosystems. On socialecological systems see Brian Walker et al., 'Resilience, Adaptability and Transformability in Social-Ecological

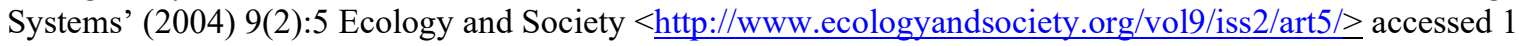
July 2020.

${ }^{43}$ Eric Katz, Nature as subject: Human Obligations and Natural Community, (Rowman and Littlefield 1997), 13. See also, Ben Almassi, 'After Exploitation and Degradation: Prospects for a Model of Environmental Restorative Justice' (2016) Citizenship, Restorative Justice, and the Environment $<$ https://www.academia.edu/20228455/After_Exploitation_and_Degradation_Prospects_for_a_Model_of_Envir onmental_Restorative justice_2016 > accessed 1 July 2020.

${ }^{44}$ In this respect, Chaitanya Motupalli, 'International Justice, Environmental Law, and Restorative Justice' (2018) 8 Wash j Envtl L \& Pol’y 333.

${ }^{45}$ Brian Preston, 'The Use of Restorative Justice for Environmental Crime' (2011)

$<$ https://www.lec.justice.nsw.gov.au//Documents/preston_use $\% 20$ of $\% 20$ restorative $\% 20 j u s t i c e \% 20$ for $\% 20$ envir onmental\%20crime.pdf $>$ accessed 1 July 2020.
} 
The focus on New Zealand (NZ) pursues a twofold purpose. Firstly, to describe how RJ for environmental crimes works in practise. Secondly, to highlight the systemic conditions that allow an organic development of RJ in NZ's legal framework. ${ }^{46}$ This point will be discussed last after having provided the reader with the relevant normative ground and an exemplificatory case-study.

\subsection{The legal framework}

NZ has been a pioneer in endorsing RJ approaches to crimes. ${ }^{47}$ The Sentencing Act 2002 (Sentencing Act) integrated RJ goals into NZ's criminal justice system, forming part of the sentencing process. Section 7 of the Sentencing Act outlines nine sentencing purposes, the first four are restorative in nature. They include: a) holding the offender accountable for harm done to the victim and the community by the offending; b) promoting a sense of responsibility or acknowledgment of the harm in the offender; c) incorporating the interest of the victim of the offence; and d) providing reparation for harm done by the offending. ${ }^{48}$ The Sentencing Act, Section $8(\mathrm{j})$ 'Principles of sentencing' states that a sentencing judge 'must take into account any outcomes of restorative justice' ${ }^{49}$

Further, the Victims' Rights Act 2002, as amended in 2014, ${ }^{50}$ incorporates RJ provisions by requiring courts, police or a probation officer to comply with a victim's request to meet the offender to resolve issues relating to the offence. ${ }^{51}$ These provisions apply for all crimes, including environmental criminal offences codified in the Resource Management Act 1991 (RMA), enacted to promote the sustainable management of natural and physical resources. ${ }^{52}$ When a prosecution is initiated under the RMA, proceedings must be presided over

\footnotetext{
46 The focus on NZ is because this country has organically implemented RJ for environmental crimes, while in other jurisdictions, such as Australia, such solutions have been object of occasional experiments. For a comparative analysis between NZ and Australia's legal orders, see Nicola Pain et al., 'Restorative justice for environmental crime: an antipodean experience', (2016) International Union for Conservation of Nature Academy of Environmental Law Colloquium, 47,

$<$ http://www.lec.justice.nsw.gov.au/Documents/Speeches\%20and\%20Papers/PainJ/Pain\%20J\%20$\% 20$ Restorative $\% 20$ Justice $\% 20$ for $\% 20$ Environmental $\% 20$ Crime $\% 20$ \%20\%20an\%20Antipodean\%20Experience.pdf> accessed 20 June 2020; Al-Alosi, Hamilton (n 14).

${ }^{47}$ For historical overview of RJ development in NZ, see Sarah Pfander, 'Evaluating New Zealand's restorative promise: the impact of legislative design on the practice of restorative justice' (2020) 15:1 Kōtuitui: New Zealand Journal of Social Sciences Online 170.

${ }^{48}$ Sentencing Act, Section 7(1) 'Purposes of sentencing or otherwise dealing with offenders'.

${ }^{49}$ This principle is further reaffirmed by Section 10 of the Sentencing Act.

${ }^{50}$ NZ Victims' Rights Act 2002 No. 39.

${ }^{51}$ Ibid, Section 9(2).

${ }^{52}$ As stated in RMA's section 5(1).
} 
by a District Court Judge, who is also an Environment Judge, ${ }^{53}$ to whom purposes and principles of sentencing established in Sections 7 and 8 of the Sentencing Act apply.

\subsection{Restorative conferences for environmental crimes.}

According to the 2012 NZ's Ministry of the Environment report, between 1 July 2001 and 30 September 2012, restorative conferences were used in 33 prosecutions pursuant to the RMA. ${ }^{54}$ The most prevalent model in NZ for environmental crimes is back-end conferencing that occurs before sentencing if the offender pleads guilty. ${ }^{55}$ This model is highly inclusive, involving not only victims and offenders, but also community members, Council offices, councillors and indigenous New Zealanders. ${ }^{56}$ Case-law highlights that restorative justice processes enable a wide range of outcomes to redress aspects of the offence beyond what could be achieved by only applying the statute. ${ }^{57}$ Examples include an apology, ${ }^{58}$ funding donations to environmental projects or organizations committed to environmental protection, ${ }^{59}$ payments to compensate clean-up costs, ${ }^{60}$ proposals to prevent the incident reoccurring in the future, ${ }^{61}$ and the offender to directly repairing the environmental harm caused. ${ }^{62}$

\subsection{The Canterbury Regional Council v Interflow (NZ) Ltd case}

A paradigmatic case of back-end restorative conferencing pursuant to RMA prosecutions is Canterbury Regional Council v Interflow (NZ) Ltd (Interflow). ${ }^{63}$ This case provides an example of how RJ conferencing can be innovatively integrated at sentencing. ${ }^{64} \mathrm{It}$ involved a corporation, Interflow, that contaminated a local stream by discharging the

\footnotetext{
${ }^{53}$ RMA Section 309(3).

${ }^{54}$ Ministry for the Environment (NZ), 'A study into the use of prosecutions under the resource Management Act 1991: 1 July 2008 - 30 September 2012’ October 2013 <https://www.mfe.govt.nz/sites/default/files/study-intothe-use-of-prosecutions-under-the-RMA.pdf $>$ accessed 30 June 2020.

${ }_{55}$ Plea of guilty is a precondition for RJ conferences under Section 24A(1)(b) of Sentencing Act 2002. Adult conferencing is governed by best practises, such as 'New Zealand Ministry of Justice. Restorative justice best practice framework' (2017). For an overview of front-end models, see Margaret McLachlan, 'Environmental Justice in Canterbury' (2014) 37(4) Public Sector 22.

${ }^{56}$ RMA Section 267 regulates conferences procedures. The importance of ensuring a high degree of participation in RJ conferencing regarding environmental offences was stressed by District Court in Bay of Plenty Regional Prosecutor v Withington [2018] NZDC [39].

${ }^{57}$ Nicola Pain 'Encouraging Restorative Justice in Environmental Crime' (2018) 13 Newcastle L Rev 29.

${ }^{58}$ Southland Regional Councill v Taha Asia Pacific Ltd [2015] NZDC [24].

${ }^{59}$ Auckland Council v MJ Green Ltd [2018] NZDC [15].

${ }^{60}$ Waikato Regional Council v PIC NZ Ltd [2004] Auckland District Court [58].

${ }^{61}$ Ibid.

${ }^{62}$ Auckland Regional Council v PVL Proteins Ltd [2008] DCR [84]. For further case law, see Pain (n 46); AlAloisi, Hamilton, (n 14), 1474.

${ }^{63}$ Canterbury Regional Council v Interflow Ltd [2015] NZDC.

${ }^{64}$ For additional discussion of this case, see Vanessa Sugrue, 'What happens when values are put to work? A reflection in one outcome from a Restorative Justice conference in the criminal division of the District Court: Environment warranted judge decision’ (2015) Resource Management Journal 19.
} 
chemicals used to reline culverts into the water. As a result, eight native fish species, four with cultural significance for the local community, were decimated. Local people from Runanga, which gathered watercress from the stream, was affected as well. ${ }^{65}$ Complaints were brought before the Canterbury Regional Council and once the case entered the Court process, Interflow took responsibility and accepted to take part in a restorative justice conference. ${ }^{66}$ The offender, representatives of Runanga and members of the Canterbury Regional Council also participated in the conference.

The court report illustrated that Interflow listened to those attending, acknowledged the cultural and ecological significance of polluting the environment for involved communities, and showed remorse. ${ }^{67}$ Furthermore, the corporate offered $80.000 \mathrm{NZ}$ dollars to implement an ecological plan to enhance the stream and improve affected fish habitats in the polluted stream and another nearby stream. ${ }^{68}$ A neutral agency under the consent of Christchurch City Council was to supervise the plan's implementation. ${ }^{69}$ Notably, this sum was considerably higher than the expected fine the prosecutor would have applied for the breach of the law. ${ }^{70}$ When the case returned to Court, the outcomes of the conference were scrutinised. As these amendments were considered adequate, the final decision was to convict and discharge Interflow with no further penalty. ${ }^{71}$

In the words of the prosecutor, conferencing was beneficial because 'so much more was achieved [...] by leaving their involvement at paying a monetary fine and walking away from the damage done'. 72 "Much more" refers to the creative outcomes reached for the environment and the people part of that environment. Communities were empowered as they had a voice in the process and could directly confront the offender, who subsequently apologised. The sum donated was higher than the expected fine and tailored to cover costs for repairing the harm inflicted on the environment. Arguably, the offender also benefitted as they saved the cost of the process and minimized reputational damage and community backlash.

\footnotetext{
${ }^{65}$ Interflow (n 63) [16]-[18].

${ }^{66}$ Ibid [42]. RJ conferences are organised by local provider, a list of which is available at

$<$ https://www.justice.govt.nz/about/lawyers-and-service-providers/service-providers/restorative-justiceproviders/list-of-rj-providers/> accessed 20 June 2020.

${ }^{67}$ Interflow (n 63) [42]. Note that the conferring discussion is confidential and thus not available.

${ }^{68}$ Ibid [43].

${ }^{69}$ Ibid [45]-[46].

70 That would have been about $\$ 33,750$. Ibid [42]; [47].

71 Ibid [47].

${ }^{72}$ Sugrue (n 64), 22.
} 
What ultimately marks the difference between these results and traditional remedies, such as fines or clean-up orders, is the relational realm in which these outcomes are framed. A traditional clean-up order focuses on physical damage per se, without expanding the focus to include harm as part of a more complex relationship with human beings in the community. Therefore, from a RJ perspective, reparations or other tangible outcomes, such as compensation, can restore parties if they form part of a more complex and dialogical process among stakeholders. This requires the offender to accept accountability for their wrongdoing, understand the whole spectrum of consequences stemming from their behaviour, and consequently provide remedies tailored to address and wholly resolve the harm. In this way, the message of domination enshrined in the crime is withdrawn and the relational realm can be healed. This is what happened in the Interflow case.

\subsection{Lessons from New Zealand}

The use of RJ for environmental crimes in NZ must be examined under systemic considerations. As discussed in section 2.3, environmental harm due to crime has a broad relational scope, in which eco-centric and anthropocentric dimensions are intertwined and equally affected. The ability of RJ to recognise the relational nature of environmental harm justifies the implementation of RJ for environmental crimes. This is despite RJ' $s$ traditional restricted focus on inter-individual crimes. Such a conception of the environment finds statutory recognition in NZ's legal framework. Indeed, the RMA adopts a relational definition of the environment that encompasses more than the sum of environmental matrices jeopardised by crime because it includes 'the social, economic, aesthetic, and cultural conditions' ${ }^{73}$ This is arguably a factor that enables the adaptation of RJ to such a field. There is more.

By incorporating RJ within the Sentencing Act, NZ's legislature showed commitment to go beyond mere retributive solutions by binding courts to pursue RJ principles in sentencing. This seems to reflect a political willingness to reduce the State's monopoly in punishing crimes, giving the opportunity to individuals to play an active role to rectify the consequences stemming from crime. This does not mean that NZ's authorities dismiss their role in prosecuting criminal offences. As discussed earlier, conferencing integrates, but does not substitute for sentencing as the court retains control over the case. The Sentencing Act proves that retributive logic is not the only option and that individual's commitment to address wrongs must prevail over punitive logic when sentencing. In a nutshell, the holistic understanding of

\footnotetext{
${ }^{73}$ RMA Section 2.
} 
the environment and the political aim to restore harm rather than simply punish offenders are systemic conditions that make RJ implementation in NZ possible.

\section{The EU's top-down approach for environmental crimes}

Bearing in mind the foregoing conclusions regarding the NZ model, the following section discusses how the EU legal order could adopt RJ solutions for environmental crimes, in addition to its current remedies. This will be achieved by advocating compliance between $\mathrm{RJ}$ rationales and the evolution of the EU legal order, including its environmental policy.

\subsection{Effective, dissuasive, and proportionate criminal penalties}

After a long debate, ${ }^{74}$ the EU adopted the Environmental Crimes Directive $(\mathrm{ECD})^{75}$ in 2008. It implements the "polluter pays" principle (PPP), currently enshrined in art. 191(2) of the Treaty on the Functioning of the European Union (TFEU), ${ }^{76}$ by means of criminal law measures. However, the ECD does not reference the type and level of criminal penalties since the Court of Justice of the European Union (CJEU) held that 'the determination of the type and level of the criminal penalties to be applied does not fall within the Community's sphere of competence. ${ }^{77}$ Accordingly, art. 5 merely requires Member States to enforce effective, proportionate, and dissuasive measures to criminalise environmental misconduct. ${ }^{78}$

The notion of effectiveness is relevant for our purposes and warrants further reflection. ${ }^{79}$ Effectiveness is a relational concept. It presupposes a functionalist nexus between particular goals set by the policy maker and the instruments used by the policy

\footnotetext{
${ }^{74}$ For details about the road toward ECD's adoption, see Françoise Comte, 'European Environmental Law Review' (2006) Criminal Environmental law and Community Competence 190; Martin Heidemann-Robinson, 'The emergence of European Union environmental criminal law: a quest for solid foundations' (2008) Environmental Liability 71.

${ }^{75}$ Directive 2008/99/EC “On the Protection of the Environment Through Criminal Law" (19.11.2008).

${ }^{76}$ OJ C-326, 26.10.2012.

${ }^{77}$ Case C-440/05 (GC), Commission of the European Communities v Council of the European Union (2007) ECR I-9097, §70. This is because at the time in which the ECD was adopted, the European Community did not enjoy criminal law competences, these latter being introduced only later under articles 82 and 83 of the Lisbon Treaty. In this respect, see Diane Ryland, 'Protection of the environment through criminal law: a question of competence unabated?' (2009) European Energy and Environmental Law Review 91.

${ }^{78}$ Those listed in ECD's articles 3 and 4. For an analysis of these requirements, see Michael Faure, 'Effective, Proportional and Dissuasive Penalties in the Implementation of the Environmental Crime and Ship-source Pollution Directives: Questions and Challenges' (2010) European Energy and Environmental Law Review 256, 259. See also Report 'Environmental Crime - Reviewing the EU Rules' (2020)

$<$ https://ec.europa.eu/info/law/better-regulation/have-your-say/initiatives/1930-Environmental-Crime-DirectiveEvaluation/public-consultation> accessed 4 July 2020.

${ }^{79}$ On EU law effectiveness, see Francis Snyder, 'The effectiveness of European Community Law: Institutions, Processes, Tools and Techniques’ (1993) 56 Modern Law Review 19.
} 
maker to reach such goals. ${ }^{80}$ In our case, a criminal law penalty system (the instrument) based on the PPP must be enforced to comply with the EU's high level of environmental protection, according to former art. $174(2)^{81}$ of the Treaty Establishing the European Community (TEC). ${ }^{82}$

To achieve these goals, the ECD enforces a punitive system mainly based on deterrence logic, as stated by Preambular paragraphs no. (3) and (5) ECD. ${ }^{83}$ This is consistent with the EU Commission's statement that penal punishments are intended to be more dissuasive, and thus more effective, than civil or administrative measures. ${ }^{84}$ Thus, remedies for environmental offences, such as cleaning-up orders, must fulfil a punitive purpose, coherently with the wording of aforementioned art. $5 .{ }^{85}$ Clearly, the ECD's measures follow a punitive top-down approach based on a deterrent justification where the convicted polluter is the passive object of such penalties.

Therefore, the relevant question for our purposes is if the notion of effectiveness also justifies the adoption of participatory bottom-up restorative processes, in addition to traditional punitive top-down measures. To answer this question, the next section argues that the EU is politically committed toward the protection of a holistic notion of environment. This justifies the adoption of positive and complex solutions aimed at managing the whole environmental criminal phenomenon, rather than being simply limited to pursue the punishment of the offender. To address this point, the rationale behind the PPP, which underpins the ECD, will also be discussed. Then the analysis will propose that the EU's legal framework offers the legal basis for stakeholders' involvement in the managing of environmental criminal offences.

\footnotetext{
${ }^{80}$ Faure (n 78), 259.

${ }^{81}$ Currently, art. 191 TFEU.

82 OJ C 325, 24.12.2002. See ECD's Whereas no. 1.

${ }^{83}$ Preambular paragraphs no. (3) and (5) state that in order to achieve effective environmental protection, there is the need to adopt criminal law penalties as being more dissuasive than civil or administrative ones. On the use of criminal law to implement the principle of loyalty ex art. 4(3) TEU through deterrence see Hester HerlinKarnell, The Constitutional Dimension of European Criminal Law (Hart 2012).

${ }^{84}$ Commission Proposal of 9 February 2007, COM (2007) 51 Final, 2007/0022 (COD), particularly $§ 1$ “(...) only criminal penalties will have a sufficiently dissuasive effect for several reasons". About studies supporting Commission's statement, see Jacob Oberg, 'Criminal Sanctions in the Field of Eu Environmental Law' (2011) 2 New J Eu Crim L 402, 406. For a critical view, see Anthony Ogus and Carolyn Abbot, 'Sanctions for pollution: Do we have the right regime?' (2002) 14 Journal of Environmental law, 283.

${ }^{85}$ ECD article 5 'Penalties' states that "Member States shall take the necessary measures to ensure that the offences referred to in Articles 3 and 4 are punishable by effective, proportionate and dissuasive criminal penalties".
} 


\subsection{Effectiveness for what?}

The PPP constitutes one of the core principles of the EU's environmental policy. ${ }^{86}$ However, the content of the PPP is not yet firmly established. ${ }^{87}$ When first introduced in the European Economic Community (EEC) legal order, ${ }^{88}$ the PPP was a principle of economic efficiency to prohibit State aid. Thus, it complied with the neoliberal emphasis on free market economics pursued by Member States. ${ }^{89}$ Its core argument was that pollution was a negative externality to be internalized by the polluter as management costs. This would incentivise less pollution as polluters would avoid additional costs. The PPP's function was to avoid the polluter's unduly advantageous positions on the market in case costs related to pollution reduction strategies would have been shouldered by Member States. ${ }^{90}$

With the adoption of the Maastricht Treaty and Amsterdam Treaty, the environmental protection became a core political goal for the Community, teleologically orientated to fulfil the newly overarching principle of sustainable development. ${ }^{91}$ This principle, adopted for the first time in 1992 by the Maastricht Treaty, ${ }^{92}$ is now a guiding principle for EU's policy, recognised by art. 37 of the Charter of Fundamental Rights of the European Union (CFREU). ${ }^{93}$ It was also restated by the Lisbon Treaty ${ }^{94}$ and confirmed by EU's adhesion to the Sustainable

\footnotetext{
${ }^{86}$ According with Art. 191(2) TFEU, which also establish the principles of precaution, of prevention and of rectification of environmental damage at source.

${ }^{87}$ For an historical reconstruction of the PPP see Philippe Sands, Jacqueline Peel (eds), Principle of International Environmental Law, (3rd edn, CUP 2012); Giovanni Moschella, Anna Maria Citrigno (eds) Tutela dell'ambiente e principio chi inquina paga (Giuffrè 2014). For an analysis of the PPP in the EU legal order, see Nicolas de Sadeleer, 'The Polluter-pays Principle in EU Law - Bold Case Law and Poor Harmonisation', (2020) National Taipei University Law Review 114, 129; Petra Lindhout, Berthy van den Broek, 'The Polluter Pays principle: Guidelines for Cost Recovery and Burden Sharing in the Case Law of the Europen Court of Justice' $<$ https://www.utrechtlawreview.org/articles/abstract/10.18352/ulr.268/> accessed 18 October 2020.

${ }^{88}$ In 1973 by the First European Environmental Action Plan, OJ C 112, Principle 5 'The cost of preventing and eliminating nuisances must in principle be borne by the polluter'.

${ }^{89}$ In this respect, see Sanford Gaines, 'The Polluter-Pays Principle: From Economic Equity to Environmental Ethos' (1991) 26 Tex Int'l L J 463, $467 \mathrm{ff}$.

${ }^{90}$ So as to ensure level playing-field among the economic actors, as explained by Grazia Maria Vagliasindi in A Farmer, M Faure and GM Vagliansindi (eds), 'Environmental Crime in Europe - Modern Studies in European Law' (Hart Publishing 2017), 45.

${ }^{91}$ Respectively, Treaty on the European Union OJ C 191, 29.7.1992 and Treaty of Amsterdam amending the Treaty of European Union OJ C 340, 10.11.1997.

${ }^{92}$ Article G of the Treaty. See also the Fifth Environmental Action Plan 'Toward sustainability' (1992-2000),

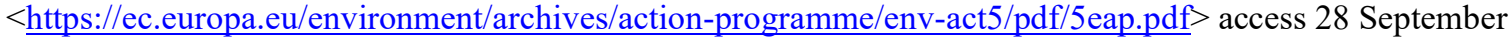
2020 .

93 Art. 37, entitled "Environmental protection" states: A high level of environmental protection and the improvement of the quality of the environment must be integrated into the policies of the Union and ensured in accordance with the principle of sustainable development.

${ }^{94}$ Treaty of the European Union (TEU) OJ C 306, 17.12.2007, Article 3(5).
} 
Development Goals (SDGs). ${ }^{95}$ Notably, the SDGs pursue a holistic and balanced integration of the three core components of sustainable development, economic development, social development and environmental protection, and their interconnections. ${ }^{96}$

This evolution produced a shift from the mere economical understanding of the PPP toward a juridical interpretation. This meant that polluters bore not only the costs of pollution but also the responsibility for damages caused to the environment and consequently to sustainability. The first binding act that recognised such a shift was the Directive on Environmental Liability. In this Directive the PPP ensured a legal basis for imposing civil and administrative liability on offenders for damages caused to the environment. ${ }^{97}$ With the adoption of the ECD, the PPP established for the first-time an explicit duty to criminalise environmental offences. This complex system of liabilities reflects a change of approach in dealing with the polluter, no longer considered as a mere economical actor vis-à-vis market rules, but rather as an active player who must comply with the EU's commitment toward sustainability.

These brief considerations could offer a first answer to the questions formulated above. Indeed, if the ECD is to implement the PPP effectively, it must duly consider the environment's social dimension recognised in the EU's sustainable development agenda. ${ }^{98}$ This implies that the notion of environment must be understood from a relational perspective, as it is the case in NZ. Thus, solutions that holistically tackle environmental crimes, focus on the harm, and pursue the restoration of an eco-centric relational realm affected by the crime, meet the ECD effectiveness test. ${ }^{99}$ Such holistic solutions would comply more strongly with the EU's political sustainability commitment than mere top-down punitive measures that, as stated earlier, focus on soloistic aspects of the crime rather than on the harm globally considered. Could these solutions be based on bottom-up restorative processes?

\footnotetext{
${ }^{95}$ Communication from the Commission, doc. COM/2016/0739.

${ }^{96}$ On the sustainable development principle, see Jeffrey Sachs, The Age of Sustainable Development, (Columbia University Press 2015). For a critical assessment on the role of environmental protection in the frame of the SDGs and for further bibliography on the topic, see Werner Scholtz and Michelle Barnard, 'The environment and the SDGs. "We are on a Road to Nowhere", in D French, LJ Kotzé (eds) Sustainable Development Goals Law, Theory and Implementations (Edward Elgar 2018).

${ }^{97}$ Council Directive 2004/35/CE on environmental liability with regard to the prevention and remedying of environmental damage, adopted following the 2000 White Book on Environment adopted in the aftermath of the oil-tanker 'Erika' disaster polluting shores around Brittany, France.

${ }^{98}$ The EU's commitment toward sustainability has recently being reinstated in the 'The European Green Deal' $\mathrm{COM} / 2019 / 640$

$<$ https://eur-lex.europa.eu/legal-content/EN/TXT/?qid=1588580774040\&uri=CELEX:52019DC0640 $>$ last accessed 31 October 2020

${ }^{99}$ In section 5.3 it will be discussed if these measures would also meet the other requirements ex ECD's art. 5.
} 


\subsection{Is there a room for bottom-up RJ processes?}

While the EU does not directly adopt RJ for environmental crimes, one can infer a preference for participatory bottom-up solutions. For example, the Victims Directive assesses basic safeguards for victims of crimes taking part in restorative processes. ${ }^{100}$ However, the Directive falls short on proactive measures to either increase availability or to guarantee equal access to RJ services for victims of crimes. The latter is the main obstacle to further develop RJ in Europe. Moreover, this Directive aims to empower the victim but says little on the role of the offender, his rights, and above all, the reparation of the harm. Therefore, the Victim Directive is per se a weak legal basis for implementing RJ's solutions for environmental crimes. $^{101}$

However, the Directive also represents a gateway for restorative practises in the EU's legal order, requiring member States to strengthen victims' role in criminal trials through participatory and inclusive solutions. As such, it supports a shift in perspective similarly to the Sentencing Act, their different legal natures notwithstanding. Furthermore, the EU's Seventh Environment Action Plan (EAP) shows an inclination toward the active participation of civil society to address and remedy environmental harms. ${ }^{102}$ In this respect, the EAP refers to nonjudicial procedures and thus it does not apply to RJ conferencing that occurs in criminal trials. ${ }^{103}$ However, the EAP is still relevant for our purposes because it encourages the inclusion of the public in the resolution of environmental matters, thereby supporting bottom-up approaches alternative to, or in addition to, traditional top-down measures. ${ }^{104}$

While these normative tools do not support RJ for environmental crimes when separately considered, they also do not forbid such solutions. These normative tools reveal a preference for inclusive and participatory bottom-up processes for dealing with environmental offences within the broader context of sustainable development. In the following section, the analysis will focus on a potential bottom-up process consistent with the deterrence function purported by ECD art. 5 .

\footnotetext{
${ }^{100}$ Directive 2012/29/EU “On the protection of victims of crimes", see Recital 46, art. 2.1(d), art. 4(j), art. 12 and art. 25. Recital 46 defines RJ consistently with the definition provided in chapter two.

101 These criticisms are brought by Katrien Lauwaert, 'Restorative justice in the 2012 EU Victims Directive: a right to quality service, but no right to equal access for victims of crime' (2013) Restorative Justice, 414.

102 Council Decision 386/2013/EU on a General Union Environment Action Programme to 2020 'Living well, within the limits of our planet'.

${ }^{103}$ Ibid., annex $\S 65(\mathrm{v})$ "non-judicial dispute resolution as a means of finding amicable and effective solutions for disputes in the environmental field".

${ }^{104}$ Article 3(2) therein states that public authorities at all levels shall work with businesses and social partners, civil society and individual citizens.
} 


\section{A RJ bottom-up approach for environmental crimes}

This section proposes a public law back-end model characterised by a hybrid nature between Victim-Offender Mediation programmes (VOMs) and NZ conferencing. On the one hand it differs from conferencing as the facilitator is present and plays a key role, as it will be discussed later. On the other, it differs from VOMs due to a high degree of inclusivity, including also public law agencies. This proposed model grants judicial overview over the case, a public monitoring system and safeguards for the fundamental rights of parties involved. In the following section, the core elements of such programmes are discussed, namely who can take part in the conferences, the conferences' nature and the consistency of RJ remedies with ECD art. 5.

\subsection{Participatory right set forth by the Aarhus Convention.}

When dealing with environmental crimes, the issue of standing for environment concerns arises. Stone argues that natural elements, such as rivers, forests, and atmospheres, should be able to vocalise their claim through appointed legal spokespersons. ${ }^{105}$ This spokesperson could be an independent administrative authority or a governmental entity, as in the Interflow case in which the polluted river was represented by the local Council. Otherwise, or in addition, as Preston suggests, non-governmental organisations (NGOs) responsible for or engaged in the protection of the environment could have standing for pure eco-centric concerns. ${ }^{106}$ In this respect, the 1998 Aarhus Convention (the Convention) establishes a right to public participation in environmental matters and introduces the whole spectrum of environmental, social and economic interests in the decision making process with a view to strike a fair balance among them. ${ }^{107}$ Accordingly, Kofi Annan defined the Aarhus Convention as being 'the most ambitious venture in the area of environmental democracy'. ${ }^{108}$

\footnotetext{
${ }^{105}$ Christopher Stone, 'Should trees have standing: toward legal rights for natural objects' (1972) 45 S Cal L Rev 450; similarly, Roderick Nash, The right of nature - a history of environmental ethics (Primavera press 1990), 128.

106 Preston (n 45), 15.

${ }^{107}$ United Nations Economic Commission for Europe (UNECE) Convention on Access to Information, Public Participation in Decision-Making and Access to Justice in Environmental Matters.

108 See UNECE 'The Aarhus Convention - An Implementation Guide' (2000). See also Michel Prieur, 'La Convention d'Aarhus, instrument universel de la démocratie environnementale' (1999) Rev jur env 9; Alan Boyle, 'Human Rights and the Environment: Where Next?', (2012) 23(3) EJIL 613.
} 
The Convention is relevant for our purposes since it forms part of EU law. ${ }^{109}$ The CJEU ruled, in Lesoochranarske zoskupenie VLK $v$ Obvodny urad Trencin, ${ }^{110}$ that the Aarhus Convention confers on the public a right to participate 'effectively during the environmental decision-making', ${ }^{111}$ if an interest is ascertained in accordance with art. 2(5) Convention. For the purposes of this latter disposition, 'non-governmental organizations promoting environmental protection [...] shall be deemed to have an interest'. ${ }^{112}$ Accordingly, involved NGOs enjoy a right to be party to the proceeding on the simple basis of their commitment in promoting environmental protection. ${ }^{113}$ It follows that it is not necessary to have an affected, or likely to be affected, direct interest in the specific case. It is however necessary that the involved NGO speaks for the affected environment and that it does not defend its own interests. This is a case-by-case evaluation that should be carried-out by the facilitator setting the restorative conference. ${ }^{114}$

NGOs' right to participation promises to add value to the processes under examination. NGOs are often receptors of voices and perspectives closer to social realities, and thus their presence in RJ procedures for environmental crimes should be encouraged to bridge State's institutions with environmental and social spheres. ${ }^{115}$ NGOs could therefore play an active role in determining the offender's accountability, by analysing, disaggregating, and challenging data provided by the offender to assess their accuracy and the crime's implications on the relational ground. As such, a NGOs' contribution could minimise the risk of sterilising the dialogical spirit of restorative procedures in technical evaluations made by governmental or independent authorities. ${ }^{116}$ These evaluations are essential for the reparation of damaged natural matrices but not sufficient for the restoration of the environmental harm that, as discussed earlier, entails complex relational implications.

\footnotetext{
${ }^{109}$ Ratified through the adoption of Decision 2005/37. That the Aarhus Convention is part of the EU legal system is confirmed by CJ case-law, ex multiis, C-344/04 International Air Transport Association (IATA) and European Low Fares Airline Association (ELFAA) [2006], §36; C-459/03 Commission v Ireland [2006], §§8184.

110 Case C-243/15 (GC) (2015) ECLI:EU:C:2016:838.

${ }^{111} \mathrm{Ibid}, \S 46$. The CJ refers to article 6(3), (4) and (7) of the Convention.

112 Article 2(5) Aarhus Convention.

${ }^{113}$ Ex articles 2(5) and 6 of the Convention, as stated in Case C-243/15 (n 110) §49. For a comment on this case, see Massimo Contino, 'Partecipazione ai processi decisionali ed accesso alla giustizia in materia ambientale: riflessioni a partire dalla recente giurisprudenza della Corte di Giustizia' (2017) 29 DPCE $<$ http://www.dpceonline.it/index.php/dpceonline/article/view/361> accessed 3 July 2020.

${ }^{114}$ See note 125 .

${ }^{115}$ NGOs usually operates with support from experts who often are activists working on the field, thereby being more sensible, open and attentive to people's instances.

${ }^{116}$ Such risk has been prospected by Andrew Light, 'Ecological Citizenship', in R Platt (ed.) The Human Metropolis (University of Massachusetts Press 2006) 173.
} 


\subsection{The dialogical nature of bottom-up restorative process.}

Both RJ procedures and criminal law trials transform conflicts into rational and dialogical confrontation between parties. ${ }^{117}$ While the dialogic confrontation is common to both approaches, the nature of such dialogue is different. In the penal trial, parties discuss binary and exclusive options. For example, has the law been violated or not; is the accused guilty or innocent? Therefore, dialogue follows a cross-examination argumentative strategy, characterised by forms of irreconcilable oppositions. In a RJ procedure, instead, as in the Interflow case highlighted earlier, dialogue does not confute opposite theses, but rather it identifies common elements. These include how the pollution impacted victims, how to resolve the harm, and etcetera.

The perspective is thus radically different because there is the possibility to establish a form of confrontation that is not competitive but cooperative, in which the counterpart is not an antagonist but actually a co-protagonist in reaching consensus on a common understanding of the offence and on how to rectify the harm. ${ }^{118}$ In this regard, the key is that the wrongdoer itself condemns its act of violence by means of repentance, that can be expressed by offering apology or acknowledging responsibility for the harm, ${ }^{119}$ as happened in Interflow. ${ }^{120}$ Through repentance the wrongdoer seeks to transcend the static contraposition of victim/offender, deactivating the message of domination intrinsic to crime and consequently opening to cooperative behaviours. ${ }^{121}$

Cooperative confrontation concerns the understanding of how the offence affects the relational sphere and of how to restore it. However, cooperative confrontation cannot entail the determination of the basic facts over which the prosecution is initiated. Such facts must be established by public authorities and then acknowledged by parties for an RJ process to start. ${ }^{122}$ Facts constitute a justification for, but also a limit to, parties' consensus. They are a justification

\footnotetext{
${ }^{117}$ Dialogical confrontation is rooted in regulation and thus it rejects the notion of conflict as a manifestation of violence.

${ }^{118}$ In this way, Federico Reggio, Giustizia Dialogica. Luci ed ombre della Restorative Justice (Franco Angeli 2010), 137.

119 That does not amount to admission of legal guilt, see note 11 .

${ }^{120}$ On the value of repentance for punishment, see Murphy ( $\mathrm{n} 26$ ).

${ }^{121}$ On apology as a dynamic experience, see Anthony Bottom, 'Some Sociological Reflections on Restorative Justice, in Restorative Justice \& Criminal Justice (n 4), 93.

122 Parties' acknowledgment of facts is required by Recommendation $2018 \S 30$. This does not necessary entail defendant's criminal liability, as Commentary to Recommendation clarifies ( $\mathrm{n}$ 7). It is rather meant as an important step to clarify the factual background over which it is possible to build up parties' confrontation. Nevertheless, States implementing RJ can rule differently, requiring for instance a formal admission of guilt to enter in the RJ process, as NZ does (n 55).
} 
because parties' knowledge of facts attributes meaning to their consent to participate. They are a limit because if the factual basis could be an object of parties' confrontation, parties would retain a power of disposal over the prosecution and ultimately over the infringed penal statute. ${ }^{123}$ As such, this power would lead to a privatisation of the offence inconsistent with the public nature of crimes.

In this respect, Recommendation 2018 requires judicial authorities or criminal justice agencies provide the facilitator with an adequate picture of the case's factual circumstances to define the offence to which the practise is related. ${ }^{124}$ Accordingly, the key relevance of the facilitator in this bottom-up model is twofold. Firstly, it bridges a RJ conference with the penal trial, assessing the pertinence of the case for RJ services and filtering who participates in the conference based on a nexus with the harm. ${ }^{125}$ Secondly and most importantly, it ensures that parties develop a dialogue that is not only emphatic, but also rational. This results in a dialectic confrontation between them, critically assessing whether their statements are consistent with reality. The emotional dimension cannot be hegemonic; its undiscussed relevance for an approach to justice that focuses on persons notwithstanding. ${ }^{126}$ If this is the case, there is the risk that dialogue departs from facts and further risks an unbalanced confrontation which advantages the party better at imposing their own narrative. ${ }^{127}$ In short, sentiments could not create a consensus over a reality that did not happen. ${ }^{128}$

Therefore, the role of facilitators goes beyond a mere formal setting and supervision of the conference. Their presence is crucial in enhancing the cooperative aim of the restorative dialogue, by ensuring an information balance between the parties and by highlighting relevant arguments for parties and solutions to address their needs. ${ }^{129}$ Consistently, Recommendation 2018 stresses the fundamental importance that facilitators should develop not only technical

${ }^{123}$ As suggested by Reggio (n 118), 123. See also, Federico Reggio, 'Accepted or Acceptable Justice? The problem of Rational Control in restorative justice practices' (2008) $<$ www.euroforumrj.org $>$ accessed 10 October 2020, 169.

${ }^{124}$ Recommendation $2018 \S 33$.

${ }^{125}$ On the nexus with the harm, see section 2.1. This is also important to exclude those NGOs who do not meet criteria under Aarhus Convention's article 2(5).

${ }^{126}$ In this sense, Reggio (n 118), 127.

${ }^{127}$ In this respect, Natali has highlighted that in the Spanish region of Huelva, in which environmental degradation occurred due to industrial activities, concerned enterprises developed successful communicative strategies to minimise victims' perception of occurred environmental harm on their lives and consequently to escape from their liability. See Lorenzo Natali, Green Criminology. Prospettive emergenti sui crimini ambientali (Giappichelli 2015), 136.

${ }^{128}$ Albin Eser seems to suggest that cooperative rational confrontation founds consensus, not viceversa. See Albin Eser, 'La giustizia penale a misura d'uomo' (1998) Rivista italiana di diritto e procedura penale, 1063, 1079.

${ }^{129}$ A fundamental task above all for environmental offences, where often the polluter is more aware of the offence given its proximity to the source of pollution. 
skills, but also those cultural and social capabilities that would allow them to understand the relations broken by crime. ${ }^{130}$ In a nutshell, the facilitator is called to coordinate in a flexible and dynamic way the dialectic between participants, ensuring its rationality, to help parties in the process of recognition of the other which constitutes RJ's core goal.

Outcomes stemming from dialectic restorative processes are prescriptive by nature, in the sense that they prescribe which measures must be enforced to withdraw the message of domination enshrined by crime against the overall community, as previously conceptualised. ${ }^{131}$ Their content, as the NZ experience highlights, is dynamic and tailored on a case-by-case basis, and it can range from symbolic redress, such as apology, to tangible forms of reparation. In this respect, space should be afforded to what Preston labels "compensatory habitat" programmes when dealing with those cases in which the damage to the environment produced by the polluter cannot be repaired. ${ }^{132}$ Even in this situation, an offender could seek rehabilitation by demonstrating its commitment to the environment elsewhere, for example by funding cleaningup processes concerning other polluted sites, environmental research projects, reforestation programmes and similar actions. What seem to be core for such programmes is the reaffirmation of nature's intrinsic value as a constitutive aspect of community, regardless the reinstallation of the specific damage. However, this should not obscure RJ's ultimate goal of healing relations. Thus, when local communities or individuals are directly affected, such programmes must take these victims' needs into primary consideration.

\subsection{Consistency with ECD art. 5: toward the 'Polluter redresses principle'?}

In chapter four, it was discussed that restorative solutions meet the effectiveness test under ECD's art. 5. This article also requires penalties to be criminal in nature. ${ }^{133}$ ECtHR jurisprudence indicates that whether a penalty complies with this requirement is a substantive test and includes severe thresholds. ${ }^{134}$ Accordingly, RJ agreements are acts of a criminal nature when considering that offenders cannot use them to avoid sanctions. Rather, because they require the offender's active commitment in resolving issues arising from its misconduct, they

\footnotetext{
${ }^{130}$ Recommendation $2018 \S 37, \S \S 40-43$.

${ }^{131}$ Luciano Eusebi, "Gestire il fatto di reato. Prospettive incerte di affrancamento della pena "ritorsione" in C Paliero, F Viganò, F Basile and G Gatta, (eds), La pena, ancora: fra attualità e tradizione. Studi in onore di Emilio Dolcini (Giuffrè 2018).

${ }^{132}$ For example, because it would be too demanding, the damage is irreversible or, on the contrary, naturally reinstated over time. Preston (n 45), 19.

${ }^{133}$ See the wording of ECD article 5 at note 85.

${ }^{134}$ See landmark ECtHR Engel v. The Netherlands, App. no. 5100/71 (8 June 1976) §81, according to which the penal nature of a measure has to be determined having regard to its severity, the procedure under which it is adopted, the means of implementation and the nature of the offence for which it is adopted.
} 
result in solutions requiring more commitment from the offender than established punishments, as the Interflow case demonstrates. ${ }^{135}$ It follows that the two further requirements under ECD's art. 5, namely dissuasion and proportion, are met. Indeed, dissuasion is intrinsic in the afflictive character of such measures and proportionality is a bedrock principle attached to criminal law sanctions, which therefore must be respected when determining the content of RJ outcomes in sentencing. ${ }^{136}$

That said, the actual obstacle for adopting RJ measures under art. 5 is that it clearly requires such criminal penalties to fulfil a punitive function. As section 2.3 detailed, the justification underpinning $\mathrm{RJ}$ is not the punishment of the culprit, but rather the restoration of relations. Therefore, even admitting the penal nature of RJ outcomes, this requirement could be hardly met. It follows that this obstacle can be overcome by means of legislative amendment of the term 'punishable'. In this respect, a potential solution could be offered by the term 'redress' to mean a right to remedy based on "effective, proportionate and dissuasive criminal penalties". As such, the term "redress" would allow member States to resort to remedies based not only on punitive purposes but also, inter alia, on restorative ones. This solution supports a further conceptual evolution of the PPP to identify a proper legal basis for RJ outcomes.

As seen in part four, the PPP has proved to be a ductile principle that, following an evolutive interpretation, has founded the adoption of the ECD. Nonetheless, the term "pay" still reflects the PPP's economic roots. Thus, its use does not aid the complexity of restorative remedies under exam, nor the relevance of the sustainable development principle for EU's environmental policies. Therefore, it is advisable to rethink the PPP in a more holistic fashion as "polluter redresses" (PRP), to enable the EU's institutions to develop legal tools that favour the active involvement of the polluter/offender in the resolution of the physical and relational harms caused by its criminal behaviour. This conceptualisation of the PRP, unlike the PPP, would ultimately reflect the EU institutions' efforts in developing remedies to tackle environmental crimes that are more consistent with sustainable development goals than the mere imposition of deterrent sanctions.

\footnotetext{
${ }^{135}$ As also stated by judge FWM McElrea 'The role of restorative justice in RMA Prosecutions' (2004) 12(3) Resource Management Journal 1.

${ }^{136}$ The use of RJ outcomes in sentencing has broad political implications, as it entails a conception of State that goes beyond mere liberal punitive strategies. In this respect, see Philip Pettit, 'Towards a Social Democratic Theory of the State', (1987) Political Studies 537, 542.
} 


\subsection{Toward a new "command and control" regulatory approach}

In this concluding section, the analysis focuses on the command-and-control model for State intervention, ${ }^{137}$ proposing a re-conceptualisation of its compliance with the PRP in section 4.3. This re-conceptualisation is a foundational starting point for further research on this topic. It is not intended to be an in-depth analysis of a new command-and-control regime, given the limits of this art.'s length.

Braithwaite distinguished two modalities of the State's power exercise, namely "rowing" where the State is a major player compared to a marginal societal role; and "steering", where the State's role is limited to providing a direction to a rowing society by means of regulations. ${ }^{138}$ In this regard, the top-down command-and-control model enshrined by ECD, based on punitive logic, reflects a rowing State, since little if any room is left for civil society involvement. By means of penal obligations, the State conveys a message toward individuals to respect a determined legal interest, like the environment, the proper fulfilment of which is then controlled through monitoring agencies, law enforcement and judicial authorities. ${ }^{139}$ Under this perspective, the control phase constitutes a mere power of verification of individuals' compliance with the command, i.e., the penal statute. A fully "rowing" State could thus not accommodate the active involvement of parties under a RJ perspective as the "rowing" State requires an imperative and rigid exercise of power, antithetical to the dynamic nature of environmental offences that requires flexible and cooperative solutions. ${ }^{140}$

The understanding proposed here, consistent with the bottom-up approach discussed earlier, is based on an expansive notion of 'control', which does not exhaust its significance concurrently with the violation of the ex-ante command, i.e., the penal law. Rather, it requires the State to regulate the aftermath of crime by directing individuals' involvement in the rectification of the harm committed. Thus, the control phase implies that the State sets the proper conditions, procedures, and infrastructures for enabling the offender to establish dialogue, integration, and cooperation with wronged parties. It is exactly in this arena that restorative solutions emerge as an alternative to traditional sentencing by providing remedies

\footnotetext{
${ }^{137}$ Command-and-control is a state-centric regulatory technique which implies the use of legal rules backed by criminal sanctions. On regulatory strategies see Robert Baldwin et al, Understanding Regulation, (OUP 2013), 105.

138 John Braithwaite, 'The New Regulatory State and the Transformation of Criminology' (2000) 49 British Journal of Criminology 222, 233.

${ }^{139}$ On the expressive function of law, Michael Vandenberg, 'The Social Meaning of Environmental Command and Control” (2001) 20 Virginia Environmental Law Journal 191. The author refers to Robert Sunstein, 'On the Expressive Function of Law' (1996) 144 U Pa L Rev 2021 with regard to the environmental area.

140 Stuart Bell et al., Environmental Law (VIII edn OUP 2013), 245.
} 
that comply with the PRP and are tailored to the specific harm. This conceptualisation of "control" that is inclusive of bottom-up processes shifts from the traditional command-andcontrol centralist logic toward a model of environmental governance ${ }^{141}$ in which the public sphere supervises the dialogical confrontation of stakeholders for restorative purposes. Therefore, this model reflects a new regulatory approach to environmental crimes, where the rowing and steering modalities of State's intervention coexist in a balanced way. Indeed, while the State would maintain a key role in promoting and supervising RJ procedures within public criminal law proceedings, such procedures would enhance individuals" "responsibilisation"142 without leading to a privatisation of the offence. ${ }^{143}$

If this is correct then, as Frediani suggests, ${ }^{144}$ the typical command-and-control scheme is redefined as a control in light of a better command based on a symbiosis between State's intervention and bottom-up restorative processes. ${ }^{145}$ In this hybrid model, the 'command' is strengthened by the offender's active involvement in withdrawing its act of domination against the victims and the legal order. ${ }^{146}$ In other words, the reaffirmation of the infringed norm would not be the result of State's top-down punishment but rather the spontaneous outcome of a dialogical process stemming from the offender's act of repentance. This is a fundamental aspect of justice, because as Dahrendorf states, the norms' validity does not rest on sanction and power only, but also on stakeholders' consensual acceptance of it, which is reached through rational debate. $^{147}$

The reaffirmation of the norm's value, jeopardised by the perpetration of crime, is also strengthened by the system's capability to guide parties toward proper remedies. When environmental representatives, such as NGOs, independent administrative authorities or governmental agencies participate in RJ inclusive conferences ecological systems have a voice. This enable parties to reach flexible solutions suitable to address the dynamism and instability of social-ecological systems in the Anthropocene. ${ }^{148}$ As such, unlike rigid top-down sanctions,

\footnotetext{
${ }^{141}$ Michael Mason, Environmental democracy (London: Palgrave MacMillan 1999). Marit Hammond et al, 'Democracy in the Anthropocene' (2020) 19 Contemporary Political Theory 127. See also Veerle Heyvaert, 'Strategies for Environmental Regulation: The Recursive Activities of Regulation', Transnational Environmental Regulation and Governance: Purpose, Strategies and Principles (CUP 2018), 90.

142 As stated by Bottom (n 121), 107, in the meaning of individuals who make provisions for their own welfare.

${ }^{143}$ Braithwaite (n 138), 233.

${ }^{144}$ Emiliano Frediani, La clausola condizionale nei provvedimenti ambientali (Il Mulino 2019), 142.

145 These processes are considered in the environmental field more suitable than punitive and direct control tools by Giulio Napolitano, Michele Abrescia, Analisi economica del diritto pubblico, (Il Mulino 2009), 256.

${ }^{146}$ Giuseppe Rotolo, Riconoscibilità del precetto penale e modelli innovativi di tutela-Analisi critica del diritto penale dell'ambiente (Giappichelli 2018), 48.

${ }^{147}$ Ralf Dahrendorf, Legge e ordine (1985), A Bassi (tr) (Giuffrè 1991), 67.

${ }^{148}$ Dryzek (n 42), 945.
} 
$\mathrm{RJ}$ remedies offer a high degree of ecological reflexivity, such as the capability to adapt to and address changing environmental and social conditions. ${ }^{149}$ Ultimately, this dynamic regulatory approach to environmental crimes appears to encourage parties' compliance to the penal law in a better way than unilateral and rigid state-centric punitive solutions. Parties' moral and value adhesion to the legitimacy of the penal norm is indeed restored on a voluntary basis, through a dialogic and active confrontation, rather than due to top-down imposition.

\section{Conclusions}

Environmental harm due to crime is like the sum of waves stemming from the impact of a stone on a calm water surface. Whilst criminal law focuses on who launched the stone and on the impact on its own, RJ considers the whole instability produced by the impact. Of course, $\mathrm{RJ}$ is not a panacea. Its application for environmental crimes depends on the circumstances of the case and on parties' consensus. Therefore, attempting to simply substitute RJ practises for the criminal law system is simply utopian. However, when successfully applied, RJ reveals potentialities in holistically managing the environmental criminal phenomenon, beyond what could be expected by fixed, pre-ordered statutory measures. Given this potential, bringing such measures in the EU will imply a further development of the EU environmental policies toward the fulfilment of the sustainable development principle, as the discussion on the PPP demonstrated. Finally, RJ can trigger major systemic changes in regulatory approaches to crime, enhancing the role of individuals in restoring the violated legal order. Given these considerations, it is possible to conclude that the introduction of RJ processes at the EU level is a reachable and promising goal, the achievement of which would yield benefits for the victim, offender, community, environment and ultimately society as a whole.

149 On ecological reflexivity, Jonas Ebbesson, 'The Rule of Law in Governance of Complex Socio-Ecological Changes' (2010) 20 Glob Env Chang 414; Jonathan Pickering, 'Ecological Reflexivity: Characterising an Elusive Virtue for Governance in the Anthropocene' (2019) 28 Environmental Politics 1145; Jonathan Pickering et al, 'Global Climate Governance between Hard and Soft Law: Can the Paris Agreement's "Crème Brûlée" Approach Enhance Ecological Reflexivity?' (2019) 31 Journal of Environmental Law 1. 